\title{
Correction to: Exploring the multivariate technique in the discrimination of Coffea arabica $L$. cultivars regarding the production and quality of grains under the effect of water management
}

\author{
Daniel Soares Ferreira $(\mathbb{D} \cdot$ Guilherme Bravin Canal • Moyses Nascimento • \\ Ana Carolina Campana Nascimento - João Marcos Soares Ferreira • \\ José Francisco Teixeira do Amaral - Lucas Louzada Pereira - Wagner Nunes Rodrigues • \\ Wilian Rodrigues Ribeiro · Dalyse Toledo Castanheira $\cdot$ Marcelo Antônio Tomaz
}

Accepted: 7 June 2021 / Published online: 5 July 2021

(C) Springer Nature B.V. 2021

Correction to: Euphytica (2021) 217:118

https://doi.org/10.1007/s10681-021-02845-5

In the above mentioned publication, the 6th author's name contained an error and should read José

The original article can be found online at https:// doi.org/10.1007/s10681-021-02845-5.

D. S. Ferreira $(\varangle)$ · J. M. S. Ferreira - D. T. Castanheira Department of Agronomy, Federal University of Viçosa, Viçosa, Brazil

e-mail: danielccaufes@gmail.com

J. M. S. Ferreira

e-mail: joao.m.ferreira@ufv.br

D. T. Castanheira

e-mail: alysecastanheira@ufv.br

G. B. Canal

Department of Biology, Federal University of Espírito

Santo, Vitória, Brazil

e-mail: guilhermebravim@hotmail.com

M. Nascimento - A. C. C. Nascimento

Department of Statistics, Federal University of Viçosa,

Viçosa, Brazil

e-mail: moysesnascim@ufv.br
Francisco Teixeira do Amaral. The original article has been corrected.

Publisher's Note Springer Nature remains neutral with regard to jurisdictional claims in published maps and institutional affiliations. 